\title{
ФИЛОЗОФИЈАТА НА УМОТ И КОГНИТИВНАТА НАУКА КАКО ИДЕЈА ВО МАКЕДОНИЈА
}

\section{Кратка содржина}

Текстот расправа за некои клучни концепти и проблеми во современата филозофија на умот и когнитивната наука. Претставени се концептите на натурализмот, интертеоретската редукиија, функиионализмот и супервениенцијата. Направен е краток осврт на рецепиијата и иднината на филозофијата на умот во Македонија.

Клучни зборови: ФИЛОЗОФИЈА НА УМОТ, КОГНИТИВНА НАУКА, НАТУРАЛИЗАМ, ИНТЕРТЕОРЕТСКА РЕДУКЦИЈА, ФУНКЦИОНАЛИЗАМ, СУПЕРВЕНИЕНЦИЈА

Две забелешки

\section{Прва забелешка: контекст на рецепцијата}

Мотивите да напишам труд во кој ќе бидат претставени основните концепти и проблеми на современата филозофија на умот произлегоа од фактот за недоволното присуство на студии од таа област во македонската периодика. Таквите текстови навистина се потребни барем за онаа филозофски ориентирана читателска публика во Македонија која од разни причини не ја следи проблематиката на современата филозофија на умот. За време на подготовките и развивање на концепцијата на текстот, низ разговори со пријатели, колеги, студенти, забележав дека некои од „претпоставките“ на концепцијата на текстот, посебно оние што се однесуваат на придонесот на филозофијата на позитивизмот и логичкиот емпиризам на XX век не само што беа отфрлени со аргументите за нивната ирелевантност за филозофирањето како такво туку дека гледиштата и ставовите на овие филозофско-научни стојалишта се штетни за филозофијата. Нивниот став за ирелевантноста и одбивањето на овие претпоставки и обвинувањата за наводниот „сциентизам“, како отуѓување од некакво изворно филозофирање, може слободно да забележам, е традиција во нашата дражва. Затоа не е ни чудно зошто немаме македонска читателска публика која има интерес за текстови од областа на современата филозофија на умот, а камоли развиена филозофска сцена која соодветно ќе одговори на предизвиците на текстот.

Приговорот дека оваа моја дијагноза се темели на лична перцепција, па според тоа и не може да биде веродостојна за постењето на некаков проблем, би можел да го релативизирам низ неколку факти (симптоми). Отсуството на текстови од областа на филозофијата на умот од македонски филозофи и немањето чита- 
телска публика за таков вид филозофија укажува на три работи: прво, дека игнорирањето на една област од современата филозофија (филозофија на умот) која во себе ги вклучува сите современи филозофски тенденции од сите други филозофски дисциплини е образовен проблем во Македонија; второ, дека одбивањето на современата филозофија, посебно на онаа филозофска продукција која се препознава како дел од аналитичката филозофија има идеолошка заднина; и трето, отсуството на организирана научна работа од областа на когнитивната наука, како водечка и најекспанзивна научна пракса во моментов во светот. Како да се разберат овие „симптоми“ и да се постави вистинска дијагноза не е целта на овој текст. Но, нивната фактичност е доволен услов да се јават како пречка и чувство на фрустрација во конципирањето на текстот и целта што тој ја има. Долга е сенката на филозофските „шамани“ на македонската филозофска сцена и големо е влијанието на искривоколчениот марксистички хуманизам.

\section{Втора забелешка: методологија на експозицијата}

Мојот приказ на некои клучни концепти и прашања на современата филозофија на умот има необичен хеременевтски хоризонт. Методот на експозиција е куновски (Kuhn, 1970) инспириран и може да биде разбран низ дискурсот на игра. Филозофијата на умот може да биде претставена како посебна парадигма каде што се содржани сите елементи на игра: дескрипција на околината на играта, средства на играта - фигури (концепти, хипотези и др.), цел на играта, правила низа од експлицитни поставени правила за дозволени и забранети потези; стратегија - насоки за дефинирање на цели во контекст и за време на играта; тактика процес на носење одлуки согласно со барањата на играта, потезите на другите играчи и изненадувањата на играта како дел од нејзините генерални правила (на пример, делење нови карти, влечење нова карта, скриена инструкција кога ќе се дојде на ново поле за време на играта). Овој елемент на „изненадување на играта“ во филозофијата е еквивалентен на „новите“ резултати на некоја концептуална анализа, воведување на нов поим, или нови податоци на научната пракса кои не можат да бидат објаснети во рамките на парадигмата, но, сепак, мора да бидат вклучени некаде и/или на одреден начин проблематизирани. Идејата со вака претставената „игра“ на филозофијата на умот е дека од суштинска важност не е само да се cфaтат позициите и потезите на играчите, туку да се разберат нивните потези - зошто се постапува така како што се постапува: какво е значењето на нивните потези (концепти, теории) во однос на играта (целта, околината, правилата), потезите на другите и во однос на историјата на нивните претходни потези.

Можеме да ја илустрираме концепцијата на игра на следниов начин: некоја теорија или концепт за когнитивните процеси на пример - потег, треба да ја разбереме така што ги почитува правилата: а) почитување на физикалистичката слика на светот (секој единечен ентитет или настан има конечна дескрипција во вокабуларот на физикализмот - натурализам); б) го почитува принципот на редуктибилност на научните вокабулари (нивните базични екстензии и својства) на специјалните науки (на пр. психологијата) на побазичните науки (биологија, неврофизиологија) и, во крајна инстанција, на вокабуларот на физиката; в) развојот на 
теоријата или концептот или теоријата на когнитивните процеси треба да ги почитува и да ги земе предвид резултатите на науката и научните критериуми на верификација, тестирање и начин на обезбедување податоци. Стратегијата на некој играч (филозоф на умот), исто така, мора да ги почитува инхерентните правила на потегот (развој на концептот): тој мора да ги почитува правилата на логичка кохерентност и конзистентност на концептот и неговата анализа и да ги почитува епистемичките правила за оправданост на концептот (проширувачката познавателната функција). Овие „негативни правила“ не ја одредуваат директно содржината на концептот или теоријата, туку само надворешно го обликуваат „местото“ за креативноста на потегот. Тактичките одлуки во филозофијата на умот за непосредниот потег е резултат - одговор на истовремено разгледување на „изненадување на играта“, потезите на другите концепти и теории и негативно дефинираните правила. Тактиките не претставуваат само прости реакции на овие „околности“, туку се смислени чекори кои одат дотаму што се обидуваат да ги доведат во прашање потезите и правилата на играта доколку се појави неможност за смислено продолжување на играта од страна на некој играч. Идентификувањата на овие, куновски кажано „аномалии“ на играта под тековната парадигма, доведуваат до поставување на прашањето за усовршувањето на играта или нејзино редефинирање, па дури и отфрлање. Пример за такви аномалии во филозофијата на умот е прашањето за експланаторниот јаз на свеста на јазикот на невронауката, или како онтолошки да се разберат својствата кои се јавуваат како дел од физичките настани, но логички и концептуално не се редуцибилни на истите настани и својства врз основа на кои се јавуваат: дали станува збор за аномалија на објаснувањето (епистемолошки проблем) или за дуализам на својства (онтолошки проблем).

И за крај, играчите можат да се сложат за динамиката и темпото на играта преку консензус за одредени „технички“ прашања (неутрални концепти, методолошки постапки и сл.) кои ќе ја одреди атмосферата на играта и ќ ја подобри комуникацијата меѓу играчите. Такви концепти во филозофијата на умот, на пример, се постапките на индивидуација на менталните состојби - како одредување на нивниот типски идентитет (како да се анализира инстанција на ментална состојба дека е инстанција од одреден тип), прашањето на детерминација (супервениенција) меѓу две класи својства за која сѐ уште не е одлучено - повлечен потег - за тоа дали таквата детерминација е редукција на инстанции или типови ментални својства; или е постигнат консензус околу начините на „читање“ на речениците преку кои се припишуваат менталните состојби: читање de dicto/de re, транспарентно или непрозирно. Овие технички прашања се повеќе меѓници во самата игра и „место“ во играта во чии рамки се тестира оправданоста и продуктивноста на потезите.

\section{Натурализам}

Првото правило во „играта“ на современата филозофија на умот е концептите за умот и когнитивните процеси да се разгледуваат во однос на натуралистичкиот контекст. Повеќето анализи на натурализмот се согласуваат дека натурализмот како стојалиште имплицира дека природата е затворен систем кој содржи единствено природни причини и нивни последици, односно натурализмот е мета- 
физичка позиција за природата на овие каузални релации според која секоја последица во рамките на природата има природна причина. Една од општите дефиниции на натурализмот е позицијата дека сѐ што постои е природно. Роберт Ауди го дефинира натурализмот како „гледиште дека природата е единствено нешто што постои и дека сите базични вистини се вистини за природата“" (Audi, 2000, p. 98). Слична определба дава и Едвард кога истакнува дека „единствено што постои е природата, па следствено на тоа натприродното не постои“ (Edwards, 1972). Овие дефиниции ги опфаќаат општите места во речиси сите релевантни дефиниции за натурализмот, па затоа и не ни кажуваат нешто повеќе за „природата“ на натурализмот. Па сепак, една подлабока анализа може да ни открие дека, сепак, овие дефиниции се или престроги во нивните онтолошки импликации или се премногу рестриктивни. За споредба, дефиницијата на Лејси дека „светот на природата формира една затворена сфера без вклученост однадвор на души, духови или богови“ (Lacey, Alan, 2005) изгледа дека дозволува постоење на ентитети кои се надвор од природната рамка, додека во дефинициите на Ауди и Едвард таквите ентитети се исклучени. Вака дефиниран, натурализмот остава можност за постоење на други затворени системи, кои не се природни, но кои, исто така, имаат каузални системи од свој вид. Меѓутоа, доколку почетната премиса на затворениот природен систем е природната последица и настан, тогаш не е тешко да се заклучи дека постоењето на други каузални системи е ирелевантно за натуралистичкиот контекст.

Овој тип ирелевантност е клучен за разбирањето на натурализмот: или ќе се прифати една онтологија која го следи природниот каузален синџир и/или ќе се допушти постоење на натприродни ентитети и каузални синџири кои немаат каузална улога во природниот свет (Kim, 1979). Можниот приговор кон каузалното разбирање на натурализмот е определувањето на каузалниот антецеденс: доколку „природно“ е сето она што е причина на една природна последица, тогаш може да се случи на местото на антецеденсот да се појават Бог, натприродни суштества и слични ентитети. Каузалниот натурализам се чини дека е неутрален во поглед на онтологијата на носителите на каузалните вериги. Овој приговор ни кажува нешто повеќе за натурализмот кој го исклучува постоењето натприродни ентитети; покажува дека натурализмот покрај тезата за каузалната затвореност на природниот домен претпоставува и една физикалистичка онтологија. Единствено преку прифаќањето на една таква онтологија би се спречиле приговорите за недоследноста на натурализмот.

Потребата од онтологизација на прашањето за натурализмот произлегува од потребата за дефинирање на онтологијата на каузалниот антецеденс: зошто некои причини би го носеле предзнакот „природни“, а други не. Вообичаениот одговор на ова прашање е дека атрибутот „природно“ можат да го носат сите оние ентитети кои се објекти на директно искуство; но, и сите оние ентитети кои се индиректни објекти на нашето искуство, преку одредени средства и помагала. Непосредноста на директното искуство е несомнена, но како да ја разбереме „природната" даденост на индиректните објекти на искуството? Одговорот на ова прашање би било следново: еден ентитет е индиректен објект на искуството доколку 
нужно мора се изведе заклучок за неговото постоење со цел да ги објасниме настаните и ентитетите на нашето непосредно искуство. Карактеристиките на индиректниот објект на искуството мора да задоволува неколку услови: својствата кои тие ентитети ги имаат мора да бидат објаснети преку принципите на некоја фундаментална наука, како што е физиката.

Имајќи ги предвид овие согледби за натурализмот, натурализмот во филозофијата на умот се појавува како емпириско и како нормативно стојалиште. Емпириското стојалиште се манифестира преку хипотези кои се подложни на научни тестирања кои можат да ја покажат лажноста или вистинитоста на некоја теорија за умот; но, исто така, преку критериумите на научните иследувања ќe се покаже кои одлики на умот можат да бидат натурализирани, а кои не можат. Емпириското стојалиште за натурализмот во филозофијата на умот има свое ехо во една од клучните студии на филозофијата на науката на Патнам и Опенхајм (Brody \& Grandy, 1989). Според нив, не е апсурдно да се претпостави дека психолошките закони би можеле да се објаснат во термини на однесувањата на невроните во мозокот; дека тие, пак, би можеле да се објаснат во термини на нивната биохемиска конституција; а додека клетките ќе се објаснат во термини на атомската физика. Доколку се изврши ваквата редукција, тогаш ќе можеме да кажеме дека, во принцип, законите на психологијата се редуцирани/објаснети со законите на атомската физика.

Нормативното стојалиште за разлика од позитивното односно емпириското стојалиште за натурализмот во филозофијата на умот го надополнува емпирискиот принцип со проектот на натурализација на менталистичкиот дискурс. Основниот мотив на овој проект е стравот дека психологијата не може да биде научна сѐ додека објектите за кои таа зборува не се објаснат во термини на некоја фундаментална наука, а дека менталните состојби не постојат сѐ додека не се покаже дека тие се метафизички зависни од физичките состојби. Ваквиот страв е единствено возможен доколку се прифати натуралистичката онтологија.

\section{Интертеоретска редукција}

Покрај новите погледи за строгите интерсубјективни тестирања во науката, верификациската семантика и нормативниот натурализам како исходиште на натурализмот во филозофијата на умот, интертеоретската редукција претставува втор клучен контекст во кој функционира дискурсот на современата филозофија на умот. Правилното разбирање на доктрината за обединета наука и концептот на редукција како клучен концепт во интертеоретските релации е неопходен за разбирање на некои од клучните проблеми на современата филозофија на умот кои се однесуваат на конституирањето на нејзиниот дискурс, но и на начинот на кој таа ги решава некои од традиционалните прашања за умот и поставува нови.

Проектот на обединета наука започнува во рамките на раниот позитивизам и обединува две филозофски стојалишта: стојалиштето на логичко-семантичката редукција и стојалиштето за физикализмот. Карнаповото толкување на психологијата е последица на тезата за физикализмот кое во ерата на Виенскиот круг 
го бранеше заедно со Неурат. Според нив, јазикот на физиката е универзален јазик на науката преку кој можат да се изразат сите научни сознанија, вклучувајќи ги тука и психологијата и социологијата. Нивната логичка анализа наместо да ги смета исказите на психологијата како ознаки на нефизички и субјективни состојби, ги третира како диспозициски поими. Така на пример, кога ќе кажеме „Тој е возбуден“, погрешно е да се разбере дека тој исказ упатува на приватна ментална сфера која е недостапна на другите луѓе. Според Карнап, анализата на реченицата „Х е возбуден“ значи „Ако дојде до дразба од тој и тој вид, х ќе реагира на тој и тој начин“. На тој начин, преку диспозициска семантичка анализа на психолошките поими, психологијата ќе може да говори исклучиво за физички настани.

Концептот на редукција во контекст на обединетата наука често се повикува на парадигматски случаи од историјата на науката: редукщија на феноменолошката термодинамика на механичка термодинамика, редукција на оптиката на Макселовата електромагнетна теорија. Некои филозофи тврдат дека ваква редукција не може да се очекува со биологијата и психологијата, додека други се на ставот дека и посочените примери не ја покажуваат претпоставената редукција. Овие спорови произлегуваат од тешкотиите во прикажувањето на редукцијата во однос на двата темелни принципи и услови на интертеоретската редукција претставени од Нејгел:

1. Најсложените случаи на редукција се хетерогените редукции, односно кога Теоријата Т2 (теоријата која треба да се редуцира) содржи термини, искази кои не се јавуваат во теоријата Т1 (примарната или базната теорија на редукцијата). За да биде успешна редукцијата е потребно исказите и термините на Т2 да бидат или преведени на термините од Т1 или да се покаже дека тие упатуваат на исти настани, ентитети или својства како термините од Т1. Овој услов Нејгел го нарекува услов на поврзаност.

2. Откако термините на секундарната теорија Т2 кои се јавуваат само во таa теорија ќе бидат заменети со термините од примарната теорија T1, тогаш ќе мора секундарната теорија да биде изведена од примарната теорија. Овој принцип Нејгел го нарекува принцип на изводливост. Во овој контекст настануваат логички и материјални проблеми затоа што секундарната теорија би можела да биде само делумно вистинита, па оттаму и логички неспојлива со примарната теорија, коja e, на пример, целосно заснована на емпириски темели. Во такви случаи, единствено што може да се изведе е коригирана секундарна теорија од која се исклучени некомпатибилностите, и така исправената секундарна теорија ке овозможи дедуктивен след на двете теории. Но, тогаш зошто би се говорело за редукција на една теорија на друга? Зар не е подобро да се каже, како што забележуваат Кун и Фајарбенд, дека станува збор, всушност, за елиминација или замена на една теорија со друга (Nagel, 1961)!

Контекстот на расправата за интертеоретската редукција е од исклучителна важност за филозофијата на умот. Во тој контекст се инкорпорирани три важни аспекти на секоја психолошка теорија: аспектот на прифатливост и оправданост на психолошките теории во однос на генералноста на физиката како онтолошка 
позиција; начините и типовите редукција преку кои ќе се покаже нивната научна прифатливост; и аспектот на автономноста на специјалните науки во однос на физиката. Затоа е важно да се има предвид овој контекст кога разните филозофски позиции даваат различни решенија на проблемите поврзани со теориите за умот.

Со воведувањето на функционалистичките теории за умот, се појавија неколку проблеми поврзани со физикализмот како онтолошка позиција на науката. Како што видовме, функционалната анализа не имплицира каква онтологија треба да биде прифатена, дека сосема е возможно и една дуалистичка онтолошка позиција да има функционална анализа. Но, во контекст на физикалистичката онтологија прашањето на идентификацијата на менталните концепти или предикати на психолошките теории отвора нови прашања и предизвици за физикализмот (Boyd, 1980; Richardson, 1979). Доколку, како што е тоа во компјутацискиот функционализам, описот на видовите ментални состојби не зависи од квалитативните и структурните аспекти на системите кои се опишуваат, тогаш е тешко да се претпостави каква ќе биде идентификацијата на менталните состојби со одредени видови физиолошки состојби (Aydede, 2000). Со можноста за описот на менталните видови независно од структурните описи се појавува проблемот на редукцијата во филозофијата на умот.

\section{Функционализам}

Најдобар начин да дадеме воведна идеја за функционализмот во филозофија на умот е да ги реконструираме критичките забелешки кон бихејвиоризмот и кон теоријата за идентитетот (Block, 1980; Block, 1996; Jackson, Pargetter, \& Prior, 1982; Jackson \& Pettit, 1988). Проблемите со бихејвиористичката анализа и во психолошкиот и во аналитичкиот бихејвиоризам се јавуваат околу прашањата за постоењето и улогата на внатрешните состојби во објаснување на однесувањето. Според умерената позиција, постулираните внатрешни состојби, дури и да постојат, немаат никаква каузално експланаторна улога. Тоа водеше до едно радикално стојалиште дека бихејвиоралната анализа нема потреба од постулирање и признавање на постоење на менталните состојби.

Неуспешноста на бихејвиоралната анализа се состоеше во неможноста без остаток да го преведе менталниот дискурс во дискурс во бихејвиорални диспозиции. Причината за тоа се имплицитното повикување на други ментални состојби при формулирањето на бихејвиоралниот хипотетички суд. Хипотетичкиот суд, кој говори само за стимули и одговори (инпут-аутпут), нуди атомистички пристап и непотполна анализа во објаснувањето на однесувањето. Диспозиционалната редукција не може да ја опфати каузалната релација на менталната состојба со други ментални состојби, па според тоа, не може ниту да го реконструира концептот на ментални процеси како процес на ментална каузална поврзаност: процес каде што менталните состојби се причини за појавување на други ментални состојби.

Проблемот со менталната каузалност на менталните состојби како каузално посредување меѓу инпутот и аутпутот, односно концептот за менталните сос- 
тојби како каузално-експланаторно релевантни за продукција на однесувањето е возможно да се реши во контекст на теоријата на идентитетот како материјалистичка теорија на умот. Фејгеловата верзија на теоријата на идентитетот, и покрај тоа што тврди идентитет на референти, а не на значења, го следи Лајбницовиот закон за идентитет. Според овој закон, две нешта се идентични само доколку ги поседуваат сите заеднички својства $-(\mathrm{x})(\mathrm{y})[(\mathrm{x}=\mathrm{y})>(\mathrm{F})(\mathrm{Fx}=\mathrm{Fy})]$. Фејгл го употребува Окамовиот брич и истакнува „наместо да прифатиме две реалности, ние имаме само една реалност претставена во два различни концептуални системи“ (Feigl, 1967).

Може да заклучиме дека и покрај тоа што постојат одредени разлики меѓу Плејс, Фејгл и Смарт, сепак, тие застапуваат една иста позиција која ги содржи следниве елементи: приватните искуства или сензации на поединците се редуцибилни без остаток на одредени, но сѐ уште неспецифицирани настани и процеси во мозокот (теза за идентитет); тезата за идентитет е контингентна пропозиција, односно таа не е логички нужна вистина. Описите на индивидуалните приватни искуства немаат иста смисла или значење како и психолошките описи на хипотетичките мозочни процеси во кои приватните искуства се содржани; вистинитоста на тезата за идентитетот е прашање на емпириска определеност.

Функционализмот во филозофијата на умот, пред сѐ, се однесува на карактеризацијата на менталните состојби преку концептот на каузалност. Каузалната моќ на менталните состојби е поради идентитетната релација со мозочните состојби, па според тоа менталната каузалност може да се реконструира како специјален случај на физичка каузалност: бихејвиоралните ефекти се последица на менталните состојби и процеси доколку постои соодветна идентитетна релација со неврофизиолошките состојби и процеси (Antony, 1991; Audi, 1993; Baker, 1993). Формулацијата на менталните состојби и процеси во каузални термини ќе ни овозможи индивидуацијата ${ }^{1}$ (типска идентификација) на менталните состојби да ја претставиме во функционално-каузални термини, односно во термини на функционална - каузална улога. Сега би можеле да дадеме дефиниција на менталните состојби која е доволно широка и прифатлива од неколкуте функционалистички правци: менталните состојби се внатрешни состојби на организмот карактеризирани преку функционално-каузалната улога и дефинирани преку каузалните релачии со инпутот, аутпутот и другите ментални состојби.

Функционално-каузалната карактеризација на менталните состојби посочува на својство кое менталните состојби и процеси есенцијално го поседуваат и кое ни овозможува преку определени типски определби функционалните улоги и релации да ги дефинираме разните видови ментални состојби - верување, желба, страв. Определбата на менталните состојби во релациона дефиниција ја истакнува нивната реалност, каузалната ефективност на однесување или на диспозиции за поведение. Иако функционалната карактеризација претендира да ги дефинира

${ }^{1}$ Индивидуацијата претставува постапка на типска идентификација на две инстанции. На пример, две единечни ментални состојби се состојби од ист тип ако имаат иста каузалнофункционална улога. 
менталните состојби, сепак, таа не е теорија која треба да ја објасни менталноста на овие состојби, ниту да ја определи нивната онтолошка природа. Функционализмот е целосно неутрален во поглед на онтолошката супстанца на менталните состојби и на субјектите на кои тие им се припишуваат (Block, 1980).

Прифаќајќи го функционалистичкото стојалиште за менталните состојби, дискурсот односно термините и концептите е потребно да имаат прецизна семантика која ќе ја рефлектира функционалистичката карактеризација на менталните состојби. За таа потреба психолошкиот дискурс треба да се интерпретира во каузална смисла, со што значењето и употребата на менталните термини и концептите ќе се сведе на каузални денотации, додека интенционалните, феноменалните и структурните (онтолошките) денотации ќе бидат игнорирани. Така, на пример, концептот „верува дека Р“, иако денотира семантички својства, па според тоа можеме да го анализираме како интенционален концепт, со функционалистичката семантичка интерпретација можеме да го дефинираме како функционален концепт, така што неговото значење би било одредено од денотацијата на функционално каузалните својства на објектот на кои реферира. Вака реинтерпретираните ментални концепти ќе послужат за дефинирање на менталните видови и ќе ја овозможат прецизната типска индивидуација на менталните состојби: она што болката ја разликува од верувањето ќе биде прикажано во функционални концепти кои ќе реферираат на функционалните карактеристики и разлики за секој вид одделно (Cummins, 1992; Harman, 1982).

Функционализмот разликува две позиции во поглед на конструкцијата на функционалистичките теории. Иако и двете позиции се согласни во однос на функционализација на менталниот дискурс, тие не се согласни околу генералниот теоретски контекст. Функционализмот според кој дефинирањето на менталните концепти и термини може да биде направен a priori, искористувајќи го секојдневниот психолошки вокабулар и знаењето имплицирано во тој дискурс е познат како аналитички или фолк психолошки функционализам. За разлика од таквата позиција, според гледиштето познато како психофункционализам, конструкцијата на психолошките теории треба да содржи специфично развиени методи, теории и емпириски наоди кои ќе ги одредат функционално каузалните определби на менталните типови и нивните меѓусебни релации. Психофункционализмот не ја отфрла фолк психолошката рамка, туку ја смета за преттеоретска формулација на сопствениот истражувачки домен.

Како што напоменавме, функционализмот е целосно неутрален во поглед на онтолошката природа на менталните состојби. Каква ке биде природата на менталните состојби кои ги препознаваме како каузално ефективни и ги карактеризираме со референца на таа особина не е имплицирано од функционалистичкото стојалиште. Луис (Lewis, 1972), на пример, менталните состојби како носители на функционална улога ќе ги идентификува со мозочни состојби, додека Патнам (Putnam, 1967) со сосема друг вид состојба. Да потсетиме уште еднаш дека функционализмот е доктрина за каузалниот карактер на менталните состојби - каузално експланаторни за продукција на однесувањето и други ментални состојби, и многу моќно средство за типска индивидуација на менталните состојби - инстан- 
циите на ментални состојби се инстанции од ист тип ако имаат типски идентична функционална каузална улога. Мотивите за онтолошките решенија за природата на менталните состојби кои се компатибилни со функционализмот треба да се бараат надвор од функционалистичката доктрина.

\section{Компјутациски функционализам}

Идејата за компјутацискиот функционализам доаѓа од повеќе извори и претставува врска на филозофијата на умот со когнитивната наука како интердисциплинарно поле на истражувањата за умот (Block \& Fodor, 1972; Putnam, 1967). Во својот оригинален предлог за функционализмот, Патнам (1967) се повикува на Туринговата анализа на интелигенцијата преку метафората на компјутациски процеси. Во својата критика на материјалистичката теоријата на умот, која ги идентификува менталните состојби со состојби на мозокот, Патнам предлага еден сосема нов поглед на умот, повикувајќи се на компјутациските машини - компјутерите; поточно, на еден посебен вид машини кои во литературата се познати како Турингови машини (Kane, 1966; King, 1996; McCall, 1999).

Туринговата машина е апарат кој со читач се движи по бесконечна лента која е поделена на полиња каде што може да се впише по еден симбол од некоја конечна низа на знаци. Во зависност од тоа во која состојба се наоѓа и кој знак го регистрира на лентата, ќе биде детерминиран следниот чекор на машината во однос на неколку параметри:

1. ќе остане во состојбата во која се наоѓа или ќе премине во друга состојба;

2. ќе го остави симболот во полето во кое се наоѓa, ќе го избрише, или ќе го избрише и ќе впише друг;

3. ќе се придвижи по лентата во еден или друг правец, или ќе остане во место.

Во дефинирањето на компјутацискиот функционализам, Туринговата машина се користи да покаже како е можно состојбите на еден систем да бидат дефинирани релационо - посебноста и нумеричкиот идентитет на состојбите се дефинирани преку нивните односи со други состојби и дека е сосема возможно да ги опишеме менталните состојби и процеси без да реферираме на нивната структура (квалитет, материјалност). Оттаму и возможноста различни физички системи и механизми да истанцираат иста Турингова машина, односно преку Туринговата машина може да се покаже како е возможно различни биолошки видови да имаат исти или слични ментални капацитети, на пример да чувствуваат болка.

Функционалните и структурните описи на организмите, всушност, одговараат на разликата, меѓутоа софтверот (програмскиот аспект) и хардверот (физичкиот аспект) на еден компјутациски систем, па затоа често во литературата за функционализмот се зборува за умот како програма на мозокот (Piccinini, 2003). 


\section{Редукционизмот: физикализам на типови/инстанци}

Со воведувањето на функционалистичките теории за умот, се појавија неколку проблеми поврзани со физикализмот како онтолошка позиција на науката. Како што видовме, функционалната анализа не имплицира каква онтологија треба да биде прифатена, дека сосема е возможно и една дуалистичка онтолошка позиција да има функционална анализа. Но, во контекст на физикалистичката онтологија прашањето на идентификацијата на менталните концепти или предикати на психолошките теории отвора нови прашања и предизвици за физикализмот (Boyd, 1980; Richardson, 1979). Доколку, како што е тоа во компјутацискиот функционализам, описот на видовите ментални состојби не зависи од квалитативните и структурните аспекти на системите кои се опишуваат, тогаш е тешко да се претпостави каква ќе биде идентификацијата на менталните состојби со одредени видови физиолошки состојби (Aydede, 2000). Со можноста за описот на менталните видови независно од структурните описи се појавува проблемот на редукцијата во филозофијата на умот.

\section{Редукционизмот: физикализам на типови/инстанции}

Имајќи го предвид класичното разбирање на интертеоретската идентификација, како идентификација на еден тип (вид) ентитети со друг, по базичен тип (вид) ентитети, може да се забележи дека во контекстот на компјутацискиот функционализам таквата идентификација е контингентна. Стојалиштето на типската идентификација, односно физикализмот на типови тврди дека за кој било од психолошките предикати $\mathrm{P}$ постои некој неурофизиолошки предикати $\mathrm{N}$, така што некој организам се наоѓa во состојбата $\mathrm{P}$ ако и само ако се наоѓa во состојбата $\mathrm{N}$ (Fodor, 1974). Во контекст на ова стојалиште се тврди идентичност меѓу психолошките и неврофизиолошките состојби и својства. Овој начин на идентификација повлекува еден вид редукција (редукција на типови) која има и онтолошки импликации.

Редукционизмот на типови се поставува и во контекст на концептот на обединета наука, така што не треба само теоретските термини и концепти да бидат редуцирани на базичните дискурси, туку и можност предикатите на психологијата преку неврофизиологијата да бидат сведени на предикатите на физиката. На тој начин, својствата и состојбите за кои психологијата тврди дека постојат не се ништо друго туку својства и процеси кои можат да бидат опишани од физиката.

За разлика од физикализмот на типови, физикализмот на инстанции тврди дека за кој било психолошки предикат Р постои некој неурофизиолошки предикат $\mathrm{H}$, така што некој организам се наоѓ во состојба Р ако и само ако се наоѓа во состојба Н од овој или оној вид. Додека во редукционизмот на типови се тврди идентитет на состојбите или својства на цела класа, во физикализмот на инстанции се тврди идентитет на поединечни ментални состојби со поединечни неурофизиолошки состојби. Физикализмот на типови го вклучува во себе физикализмот на инстанции, но не и обратно (Horgan, 1993). 
Редукционизмот во физикализмот на инстанции не претставува типска редукција, туку само ја потврдува физикалистичката онтологија според која светот во крајна инстанција се состои од физичките настани и ентитети. Може да се каже дека редукционизмот на инстанции одбива секаков вид онтолошки монизам и имплицира одреден дуализам на својства. Во однос на монизмот, редукционизмот на инстанции би дозволил и идеализам, но не и редукционизам доколку одредени типови својства се претстават како единствени во објаснување на психолошките инстанции. Тоа покажува дека онтолошката позиција во рамките на физикализмот на инстанции е придодадена позиција која зависи од онтолошката обврска на теоријата (Kim, 1989).

Компјутацискиот функционализам е компатибилен со физикализмот на инстанции по неколку основи: психолошките предикати не имплицираат никаква посебна онтологија, а нивната типска индивидуација (таксономија) претпоставува само функционално-каузална дескрипција (Fodor, 1968). Затоа физикализмот на инстанции уште се одредува и како нередуктивен физикализам, резервирајќ ја одредбата „редуктивен“ и „материјализам“ само за физикалистичкиот редукционизам на типови (Horgan, 1993; Markic, 2002).

\section{Повеќекратна реализација и супервениенција}

Концептот на повеќекратна реализација на менталните видови е дефиниран во стојалиштето на компјутацискиот функционализам и во концепцијата на физикализмот на инстанции (Bechtel \& Mundale, 1999; Bickle, 1992). Историски погледнато, прв пат аргументот за повеќекратната реализација го изложува Патнам кога го критикува стојалиштето на теоријата на психофизичкиот идентитет, додека Фодор го разработува и поставува како класичен аргумент против редуктивниот физикализам и како клучен аргумент за функционализмот (Fodor, 1974).

Стојалиштето за „повеќекратната реализација“ во филозофијата на умот изворно претставува аргумент против типската идентификација на менталните состојби. Според Патнам (Putnam, 1967), типската идентификација претпоставува дека сите суштества способни да истанцираат одреден тип ментална состојба, исто така, треба да имаат ист тип неурофизиолошка состојба, што според Патнам е нереално да се очекува дека е навистина така. Доволно е само да се прегледаат фактите на компаративната невроанатомија и физиологија да се забележи дека мноштво живи суштества за кои веруваме дека имаат одредени капацитети за психички живот (па дури и окотоподот како што наведува Патнам) немаат иста неурофизиолошка структура иако може да тврдиме дека сите овие суштества се способни да бидат во менталната состојба на болка, на пример. Доколку редуктивниот физикализам е вистинит, тогаш мора да постои заеднички тип неурофизиолошко својство заедничко низ сите варијатети на биолошки структури, односно животински видови (Bolender, 1995). Доколку редуктивната идентификација се постави како емпириска теза во согласност со научната формулација на законите, тогаш доколку се идентификува одредено неурофизиолошко својство од одреден тип како редуктивно својство на некој ментален тип, како што е кај човекот, на пример, тогаш ќе се очекува дека такво својство треба да биде инстанцирано и кај остана- 
тите организми способни да го имаат истиот ментален тип. Меѓутоа, таквото инстанцирање е невозможно токму поради различната неврофизиологија (Kim, 1992).

Тезата за повеќекратната реализација на менталните типови својства би можеле да ја претставиме на следниов начин: а) сите типови ментални својства се повеќекратно остварливи во дистинктни физички видови својства; б) доколку некој тип ментално својство е повеќекратно остварлив во различни физички својства, тогаш тој не може да биде идентичен со некој специфичен физички тип својства; в) ниту еден тип ментално својство не е идентично со кој било специфичен тип физички својство (Francescotti, 1997).

Според некои теоретичари, како што е Ким (Kim, 1997), стојалиштето за повеќекратната реализација не е поврзано со воведувањето на машинската метафора во филозофијата на умот, иако многу критичари експлицитно ја посочуваат таквата поврзаност. Аргументот за повеќекратната реализација не имплицира прифаќање на стојалиштето на компјутацискиот функционализам затоа што тој само ја исклучува можноста за типска идентификација. Сепак, ова стојалиште коинцидира со компјутерската метафора и поделбата на софтвер/хардвер во описите на организмите (Ross, 1999). Дека концептот на повеќекратната реализација е имплицирана од машинската метафора се темели на фактот дека еден компјутациски систем може да биде реализиран односно направен од различни материјали. На тој начин умот може да се сфати преку софтверската метафора, како програма може да биде имплементирана низ различни хардверски системи.

Теоријата на супервениенција (Kim, 1984) е теоретски апарат со цел да се определат врските меѓ одредени основни ентитети и повисоките или поголемите целини кои претставуваат структурирана комбинација на таквите ентитети (Bontly, 2002; Garcia-Carpintero, 1994; Kim, 1993). Таа има широка теоретска примена и може да се примени на каузалноста, во определување на моралните вредности и поими, во онтологијата итн. Тука ќе ја прикажам основната примена на проблемот ум - тело (McLaughlin, 1995).

Понекогаш супервениенцијата во смисла на супервенирање на менталното над физичкото се карактеризира со следниве искази: а) нужно, доколку постои разлика во менталното, постои и разлика во физичкото; б) нужно, доколку нема разлика во физичкото, нема разлика ниту во менталното; в) не е можно да постои разлика во менталното, и да нема разлика во физичкото (Kim, 1999).

Да ги разгледаме трите наведени пропозиции со помош на кои ја определивме супервениенцијата. Кажано со речникот на супервениенцијата, со првата пропозиција се определува во базата на супервениенцијата дека мора да постои физичка разлика доколку имаме различни ментални настани. Доколку имаме два различни ментални настани, мора да имаме два различни (микро) физички настани како нивни субвениенти. Овие (микро) физички настани, секој за себе, конституираат ментални настани; менталниот настан е возможен само доколку се реализирани некои (микро) физички процеси. Истиот (микро) физички процес секогаш е основа на ист ментален процес (Beckermann 1992). Исто така, можно е еден ист 
вид ментални процеси да супервенираат над различни (микро) физички настани. Вака формулираната супервениенција во филозофијата на умот најчесто се користи во физикализмот на инстанции, но секако може да се формулира и во форма за физикализмот на типови.

\section{Финални забелешки}

Скептичен сум за можноста од развој на филозофијата на умот како филозофска дисциплина во Македонија. Ниту едно енциклопедиско прикажување на основните концепти и проблеми на современата филозофија на умот нема да има никаков ефект затоа што клучните претпоставки за разбирање на таквиот приказ не се позитивно примени или, пак, се игнорирани од филозофската јавност, било да е таа само читателска или онаа професионалната. Тоа дека состојбата со развојот на новите тенденции од областа на филозофијата на умот и науката која се занимава со когнитивноста е на такво ниско ниво во Македонија укажува и фактот дека од сите земји во опкружувањето само Македонија нема организирана научна работа од полето на когнитивната наука. Неодамна, иницијативата (проект предложен до органите на ФЗФ за отворен конкурс на УКИМ) од неколку ентузијасти, професори и професорки од разни дисциплини на Филозофскиот факултет - УКИМ (меѓу кои и јас) да се започне со организирано работење на когнитивната наука, преку мапирање на потенцијалите за научната работа од таа област, се покажа јалова. И покрај тоа што Универзитетот има задача да ја развива научноистражувачката дејност преку воведување и поддршка на научна работа која ќ ја збогати и развие македонската наука, се покажа дека одговорните, во чии раце лежи моќта на одлучувањето, немаа слух за една од клучните мисии на Универзитетот и не ја поддржаа иницијативата. Тоа е симптом за една подлабока криза во македонската наука, посебно кај носителите на одлуки кои покажуваат хипокризија во нивните ставови, барајќи изговор во наводните процедури и приоритети. Затоа сметам дека игнорирањето и/или поддршката на корумпираноста и лукративните интереси на врхушките на универзитетските носители на одлуки (на сите нивоа на Универзитетот, вклучително и студентското организирање) само ја продлабочува агонијата на вистинската мисија и цели на Универзитетот, а ние, професорите и студентите, како директни носители на универзитетската дејност нѐ прави директни соучесници во моралниот распад на научниот живот. И науката има совест. 


\section{Литература}

Antony, L. (1991). The causal relevance of the mental, 6, 295-327.

Audi, R. (1993). Mental causation: Sustaining and dynamic. In J. Heil \& A. Mele (Eds.), Mental Causation. Oxford University Press.

Audi, R. (2000). Philosophical Naturalism at the Turn of the Century. Journal of Philosophical Research, 25, 27-45.

Aydede, M. (2000). On the type/token relation of mental representations, 2, 23-50.

Baker, L. R. (1993). Metaphysics and mental causation. In J. Heil \& A. Mele (Eds.), Mental Causation. Oxford University Press.

Bechtel, W., \& Mundale, J. (1999). Multiple realizability revisited: Linking cognitive and neural states, 66, 175-207.

Bickle, J. (1992). Multiple realizability and psychophysical reduction, 20, 47-58.

Block, N. (1980). Functionalism. In N. Block (Ed.), Readings in the Philosophy of Psychology Vol 1.

Block, N. (1996). Troubles with functionalism. In D. M. Borchert (Ed.), [Book Chapter] (pp. 268-305). MacMillan.

Block, N. J., \& Fodor, J. A. (1972). What psychological states are not. Philosophical Review,

Bolender, J. (1995). Is multiple realizability compatible with antireductionism?, 33, $129-142$.

Bontly, T. D. (2002). The supervenience argument generalizes, 109, 75-96.

Boyd, R. (1980). Materialism without reductionism: What physicalism does not entail. In N. Block (Ed.), Readings in the Philosophy of Psychology Vol 1.

Brody, B. A., \& Grandy, R. E. (1989). Readings in the philosophy of science (2nd ed). Englewood Cliffs, N.J: Prentice Hall.

Cummins, R. (1992). Conceptual role semantics and the explanatory role of content, 65 , 103-127.

Edwards, R. B. (1972). Reason and religion: An introduction to the philosophy of religion. New York: Harcourt Brace Jovanovich.

Feigl, H. (1967). The "mental" and the "physical": The essay and a postscript. Minnesota paperbacks: Vol. 10. Minneapolis: University of Minnesota Press.

Fodor, J. A. (1968). Psychological explanation; an introduction to the philosophy of psychology [by] Jerry A. Fodor. Studies in philosophy: Random House.

Fodor, J. A. (1974). Special sciences (or: The disunity of science as a working hypothesis). Synthese, 28(2), 97-115.

Francescotti, R. M. (1997). What multiple realizability does not show, 18, 13-28.

Garcia-Carpintero, M. (1994). The supervenience of mental content, 68, 117-135.

Harman, G. (1982). Conceptual role semantics, 28, 242-256. 
Horgan, T. (1993). Nonreductive materialism and the explanatory autonomy of psychology. In S. Wagner \& R. Warner (Eds.), Naturalism: A Critical Appraisal . University of Notre Dame Press.

Jackson, F., \& Pettit, P. (1988). Functionalism and broad content, 97, 318-400.

Jackson, F., Pargetter, R., \& Prior, E. W. (1982). Functionalism and type-type identity theories, 42, 209-225.

Kane, R. H. (1966). Turing machines and mental reports, 44, 344-352.

Kim, J. (1979). Causality, identity and supervenience in the mind-body problem, 4, 31-49.

Kim, J. (1984). Concepts of supervenience, 45, 153-176.

Kim, J. (1989). The myth of non-reductive materialism, 63(3), 31-47.

Kim, J. (1992). Multiple realization and the metaphysics of reduction, 52, 1-26.

Kim, J. (1993). Supervenience and Mind: Cambridge University Press.

Kim, J. (1997). The mind-body problem: Taking stock after forty years. Philosophical Perspectives, 11(s11), 185-207.

Kim, J. (1999). Supervenient properties and micro-based concepts: A reply to Noordhof, 99, 115-118.

King, D. (1996). Is the human mind a Turing machine?, 108, 379-389.

Kuhn, T. S. (1970). The structure of scientific revolutions (2nd ed., enl). International encyclopedia of unified science. Foundations of the unity of science, v. 2, no. 2. Chicago: University of Chicago Press.

Lacey, Alan. (2005). Naturalism. In T. Honderich (Ed.), The Oxford companion to philosophy (2nd ed.). Oxford, New York: Oxford University Press.

Lewis, D. (1972). Psychophysical and theoretical identifications. Australasian Journal of Philosophy, 50(December), 249-258.

Markic, O. (2002). Nonreductive materialism and the problem of causal exclusion, 63, 79-88.

McCall, S. (1999). Can a Turing machine know that the Godel sentence is true?, 96, 525-532.

McLaughlin, B. P. (1995). Varieties of supervenience. In E. Savellos \& U. Yalcin (Eds.), Supervenience: New Essays . Cambridge University Press.

Nagel, E. (1961). The structure of science;: Problems in the logic of scientific explanation. New York: Harcourt, Brace \& World.

Piccinini, G. (2003). Alan Turing and the mathematical objection, 13, 23-48.

Putnam, H. (1967). The nature of mental states. In W. Capitan \& D. Merrill (Eds.), Art, Mind, and Religion (pp. 223-231). Pittsburgh University Press.

Richardson, R. C. (1979). Functionalism and reductionism, 46, 533-558.

Ross, P. A. (1999). The limits of physicalism. Philosophy of Science 66:94-116. Schwartz, J. 1992. Who's afraid of multiple realizability?: Functionalism, reductionism, and connectionism. In J. Dinsmore (Ed.), The Symbolic and Connectionist Paradigms: Closing the Gap . Lawrence Erlbaum. 
Bobi BADAREVSKI

PHILOSOPHY OF MIND AND COGNITIVE SCIENCE AS AN IDEA IN MACEDONIA

\section{Summary}

The article discusses some key concepts and problems in contemporary philosophy mind and cognitive science: concept of naturalism, intertheoretic reduction, functionalism and supervenience. An overview is given on reception and future of the philosophy of mind in Macedonia.

Keywords: PHILOSOPHY OF MIND, COGNITIVE SCIENCE, NATURALISM, INTERTHEORETIC REDUCTION, FUNCTIONALISM, SUPERVENIENCE 